\title{
Commetáo
}

\section{Hackerspace movement: a study of the Brazilian experience}

\author{
Beatriz Cintra Martins \\ Doutora; Laboratório Interdisciplinar sobre Informação e Conhecimento, Rio de Janeiro, RJ, Brasil; \\ bia.martins@gmail.com \\ Sarita Albagli \\ Doutora; Instituto Brasileiro de Informação em Ciência e Tecnologia, Rio de Janeiro, RJ, Brasil; \\ sarita.albagli@gmail.com
}

\begin{abstract}
Hackerspaces are part of a phenomenon emerging all over the world of building alternative spaces and infrastructure for research, experimenting and learning. They differ from other institutionally established spaces in their principles of autonomy: they are financed and managed by their own members and, as a result, they enjoy greater freedom in the definition of their themes and issues. In this article, we present the results of a research project carried out in 2017 about Brazilian hackerspaces. In the analysis, we resorted to the structure proposed by Smith and others (2017) in their study about grassroots innovation movements, organized into four complementary aspects as follows: context, framings, spaces and strategies, and pathways. Thus, we contemplate the history of the movement in Brazil; meanings and narratives shared by participants; spaces and strategies employed in their structure and organization; and, finally, case studies selected because they can be articulated with the local community issues. The survey identified 21 active hackerspaces in the country in 2017, distributed in the Midwest, Northeast, Southeast and South. Sixteen of them answered a questionnaire that revealed the diversity of their activities and proximity to the university community, among other characteristics. The case studies have shown that, besides contributing to the broader circulation of technological knowledge, hackerspaces are also spaces for the development of practices and technologies that seek to answer social and environmental issues, such as sustainability in the disposal of electronic waste and citizen monitoring of the environment.
\end{abstract}

Keywords: Hackerspace. Grassroots innovation. Citizen science.

\section{Introduction}

Hackerspaces are part of a phenomenon, emerging all over the world consisting of the building and dissemination of alternative spaces for research, experimenting and learning. They can be considered as part of a set of movements in favour of open and citizen science (ALBAGLI, 2015) and grassroots innovation (SMITH et al., 2017). It is not an easy task to define them, as they can vary in structure, in the profile of participants and in the 


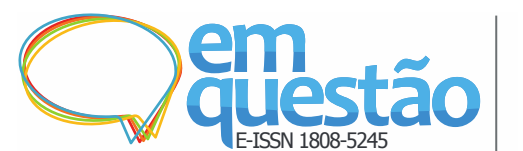

Hackerspace movement: a study of the Brazilian experience

Beatriz Cintra Martins e Sarita Albagli

types of projects being developed. The Hackerspaces.org network defines them as "[...] community-operated physical places, where people share their interest in tinkering with technology, meet and work on their projects, and learn from each other." (HACKERSPACE.ORG, 2018, doc. non-paged).

In Brazil, the landmark for this movement was the creation in 2010 of the Garoa Hacker Club, in the city of São Paulo, as the first hackerspace in the country. From then on, several similar spaces have arisen in almost every region of the country, with different setups that reveal, on the one hand, the influence of pioneering examples in Europe and the USA and, on the other, some appropriation from the Brazilian perspective. During this period, a few research projects in Brazil from different fields of knowledge have considered the theme in a greater depth, such as the work of Burtet (2014), Mattos (2014), and Menezes and Pretto (2015).

In this article, we present the results of research carried out in 2017 about Brazilian hackerspaces. Our general objective was to map out and to characterize these spaces in order to set up a detailed picture of the experience in the country. We also sought to highlight cases in which the proposals and actions of these spaces were articulated to local issues.

In the following sections, we present the results of the bibliographical survey and of the empirical research that we carried out, organized according to the following topics: employed method; conceptual framings; history of the hackerspace movement in Brazil; spaces and strategies employed in their structure and organization; and, finally, cases selected because they are articulated to local community issues.

\section{Method}

In the analysis, we resorted to the framework proposed by Smith et al. (2017) in their study of grassroot innovation movements that are organized according to four complementary aspects. These are: framings, context, spaces and strategies, and pathways.

Framings explores the meanings, values, interpretations and shared narratives, investigating cultural and ideological influences that permeate the movement under study. It refers to the place the movement occupies in broader 


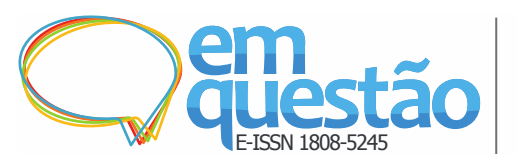

networks that act coordinately, exchanging influence in the definition of projects and priorities. In our analyses, we highlighted the dictates of hacker ethics as a specific symbolic framework for hackerspaces.

Context refers to the historical, political, economic and cultural circumstances within which a certain movement arose and, if relevant, it investigates the influence of international networks on its flourishing. In our case, we emphasized the appearance and development of hackerspaces in Brazil in connection with the emergence of a Brazilian digital culture, with reference also to the influence exerted by pioneering experiences in the Northern hemisphere.

Within spaces and strategies, the focus is on the collection of spaces and arenas - physical, political, organizational and cognitive, as well as on the repertory of actions employed to reach objectives. Within this topic, we present the results of the empirical research carried out with the help of a questionnaire, with which we tried to characterize, among others, the infrastructure of the spaces, participants profile, projects and activities being developed and sources of funding.

Finally, pathways aim to understand how the movement has contributed to generating forms of alternative development through time. Key to this topic are the material experiments developed by these spaces, be they processes or objects, which, whether corresponding or not to what was originally foreseen, represent concrete attempts of building alternative pathways. Therefore, in this section we present the initiatives that we have selected as more connected to local demands, featuring some of the projects developed by them.

In the definition of the universe for the empirical component of the study, it is important to establish from the outset that our criterion for identifying hackerspaces was one of self-denomination. This choice was made because we realized from the start of the investigation that limits existing between different types of alternative spaces for experimentation, research and the production of knowledge with a focus on technology - such as hackerspaces, makerspaces and fablabs - are, at times, somewhat blurred. Besides, there are several other similarly-inspired initiatives in the country that do not call themselves hackerspaces ${ }^{1}$. Thus, as it was our goal to understand 


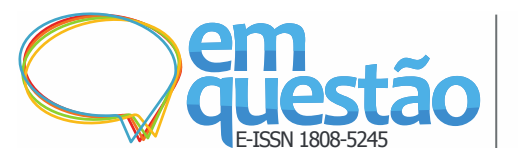

Hackerspace movement: a study of the Brazilian experience

Beatriz Cintra Martins e Sarita Albagli

the specificity of such spaces in Brazil, we chose the criterion of selfdenomination in order to set the limits to our analytical corpus.

In order to map out Brazilian hackerspaces, we started from a list organized by the Garoa Hacker Club (2019), with the addition of data available on the website Hackerspaces.org (2018). Both sites present some information about the hackerspaces listed, such as their e-mails, websites, wikis, Facebook pages, Twitter profiles and Google groups. We checked these data and we eliminated those that were unavailable or had not been updated for over a year, from May 2017. After that, we contacted each one of them to establish if they were still active; as a result, a few more were eliminated. Finally, we used the Snow Ball method to validate the data found, requesting the identified Hackerspaces participants to indicate other active hackerspaces about which they were aware. In this way, we were able to verify the redundancy between the lists initially consulted and these indications.

Based on this list, we once more established contact to invite participants to answer a questionnaire elaborated with the aim of characterizing Brazilian hackerspaces. The questionnaire was structured with 21 open and closed questions, the latter with a list of non-excluding answer options, besides the option Others for complementation and comments. We chose to host the questionnaire on the PiratePad platform, as we believed that it was an interface better-suited to our target audience who value free and non-proprietary technologies. Through the questionnaire, we could also identify four hackerspace housing projects that were related to issues from the local community. In these cases, we conducted semi-structured interviews in order to obtain in depth information and we selected one of them - the Baia Hacker for face-to-face contact. This data is presented in detail in sections 6 and 7.

\section{Framings: free technology, collaborative production and autonomy}

In general, hackerspaces place a strong emphasis on technology, science and innovation and advocate experimentation and the sharing of equipment, information, knowledge and ideas without discriminating who can participate or what kind of ideas can be explored. There is usually greater emphasis on hardware then on software, presupposing infrastructure and face-to-face 


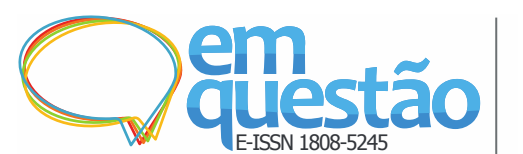

Hackerspace movement: a study of the Brazilian experience

Beatriz Cintra Martins e Sarita Albagli

meeting in physical spaces. The motivation is not to do useful things, but interesting ones.

An important framework for hackerspaces is their adherence to principles of open software and hardware as well as peer production (SMITH et al., 2017). As a result, they advocate free technology whose codes, design and instructions must be open and available to all in the context of a collaborative and decentralized production, relying on different levels of contribution from participants, according to each one's willingness, ability and knowledge.

Other similar spaces, such as makerspaces and fablabs, share with hackerspaces an interest in the possibilities for creating, adapting, repairing and producing technological artifacts. Makerspaces display great diversity, but, in general, are more directly identified with the incentive to entrepreneurship. Fablabs were conceived by the Massachusetts Institute of Technology (MIT) as platforms for learning, innovation and incentive of entrepreneurship managed by the FabFoundation, which establishes criteria, processes and regulations for their implantation.

In the case of hackerspaces, it is worth mentioning the affiliation of their participants to hacker ethics. What we would like to focus on this set of values, defined for the first time in the pioneering work of Levy $(2001)^{2}$, is a specific precept that differentiates hackerspaces from others: "distrust authority - promote decentralisation" (LEVY, 2001, p. 41). Hackerspace communities are, in general, mindful of their autonomy as they want total freedom in defining their activities and projects without requesting approval from hierarchical instances. In general, they are managed according to a model of non-hierarchical self-organization (MOILANEN, 2012).

Other steps are taken to preserve this autonomy, such as $^{3}$ : running an independent e-mail provider so as not to depend on corporate services; controlling their own space in order to define rules of use and access; remaining independent from financial support from either government or private institutions in order not to lose autonomy (most of them are financed by their own members). However, despite the fact that this is a principle stressed 


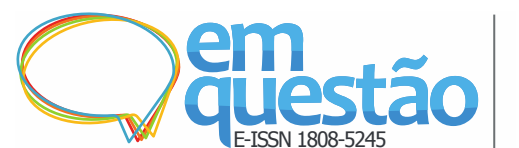

Hackerspace movement: a study of the Brazilian experience

Beatriz Cintra Martins e Sarita Albagli

by several respondents, some among the researched hackerspaces, as we will see, depend directly or indirectly on institutional financial support.

\section{Context: The emergence of hackerspaces in Brazil ${ }^{4}$}

When the hackerspace movement started in Brazil, at the end of the 2000's, there already was in the country a series of initiatives based on collaborative production, articulating digital culture with science, technology, art, activism and innovation, among other areas. The MetaReciclagem network ${ }^{5}$ can be pointed out as an example. It was created in 2002 and, within it, different groups worked recycling and repairing discarded computers, using free and open code software.

An important booster to these alternative experiences was the Programa Cultura Viva (Living Culture Programme) ${ }^{6}$, developed during the administrations of Gilberto Gil and Juca Ferreira in the Ministry of Culture in the two administrations of president Lula, from 2003 to 2010. As a result, around three thousand cultural projects in the Brazilian 26 states were selected to be funded as Pontos de Cultura (Culture Points) ${ }^{7}$, with an emphasis on collaborative production, on the use of free technology and on the adoption of alternative licences. During this period, the flowering of a Brazilian digital culture took place, characterized by the mix of digital technologies and genuinely Brazilian culture expressions, adopting practices characteristic of the neediest population in the country such as mutirão and gambiarra, two creative strategies to cope with precariousness (FONSECA, 2014). It is also important to emphasize that the Programa Cultura Livre, as a government policy, intended to stimulate social protagonism in the elaboration and administration of public policies for culture, fostering cultural diversity as a key resource for social and economic inclusion.

The mobilization for the creation of spaces for technological experimentation in the hackerspace format in the country began at the end of the first decade of the millennium. A fundamental influence that led to the arousal of interest in this format, according to Luciano Ramalho (RAMALHO, 2013) one of the founders of the first Brazilian hackerspace, the Garoa Hacker Clube, was the course Oficina de Arte e Programação (Programming and Art 


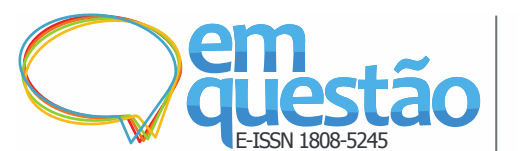

Workshop), taught by the Belgian Professor Etienne Delacroix at the Escola Politécnica da Universidade de São Paulo (Polytechnic School of the University of São Paulo) between 2006 and 2007. In fact, it was a workshop that stimulated people to lose their fear of experimentation and to play with technology. As a final task, students had to create something with left-over parts of computers and other electronic components and to document their learning process on a wiki platform, an activity similar to those carried out in a hackerspace. Halfway through 2009, the first concrete actions were taken to create a space in a virtual community built for this purpose, the HackerSPace São Paulo on Ning platform ${ }^{9}$. The idea soon attracted people with different profiles: those interested in electronics and programming; Information Technology (IT) professionals; people from the media and digital culture; people from cultural and self-managed spaces etc. ${ }^{10}$.

The influence of the movement from the Northern Hemisphere arrived next, brought to the group by some of the founders and future associates of the Garoa who, in 2010, while touring Europe and the United States for different reasons, visited some spaces such as Resistor in New York, Noise Bridge in San Francisco, and C-Base in Berlin. At their return, they brought reports from that pioneering experiences they had come across, establishing them as a reference to the movement they wanted to start in Brazil. On July 15, 2010, the first face-to-face meeting with this purpose took place at the Escritório Piloto da Escola Politécnica da Universidade de São Paulo (Pilot Office of the Polytechnic School of the University of São Paulo). At this occasion, the proposal gained greater consistency and the search for a space became concrete.

The proximity to people from the digital culture, who also took part in those discussions, facilitated the contact with the São Paulo Casa da Cultura Digital - CCD (Home for Digital Culture) ${ }^{11}$. Created in 2008 and active up to 2012, the $C C D$ offered room for the articulation of different initiatives connected to digital culture and hacker culture in the country, such as the Festival CulturaDigital.Br (DigitalCulture. $\mathrm{Br}$ Festival), the Rede CulturaDigital (DigitalCulture Network), the Rede Transparência Hacker (Hacker Transparency Network ) and the Ônibus Hacker (Hacker Bus). It was 


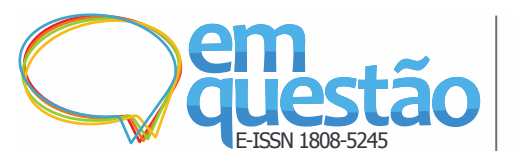

Hackerspace movement: a study of the Brazilian experience

Beatriz Cintra Martins e Sarita Albagli

also the stage for meetings debating topics of national scope such as those organized in favour of the reform of the Law of Copyrights and of the Marco Civil da Internet (Brazilian Civil Rights Framework for the Internet). The $C C D$ offered to Garoa a $12 \mathrm{~m} 2$ basement at its headquarters, a heritage building in the neighbourhood of Santa Cecília, in the central area of São Paulo. By occupying the basement of the $C D D$ for eighteen months, the Garoa most certainly absorbed the influence of this diverse audience, connected to technology, but also to culture and to activism.

Finally, on August 28, 2010, the Garoa was inaugurated and immediately started promoting its first activities and drafting its statutes ${ }^{12}$, demonstrating, from the start, the concern of setting itself up on wellestablished foundations. Two and a half years later, on February 16, 2013, the hackerspace moved into its own space ${ }^{13}$, in the neighbourhood of Pinheiros, into a five-room rented house, with a kitchen and storage area. From this moment, it could diversify its actions and broaden its audience.

Thus, we can identify the confluence of two distinct sources of influence during this early period of the hackerspace movement in Brazil. On the one hand, inspiration from references from the Northern Hemisphere, aligned with technological experimentation concerning information security, freedom of expression and privacy (GRENZFURTHNER; SCHNEIDER, 2009; MAXIGAS, 2012). On the other, the familiarity, at an early stage, with activists of digital culture in Brazil, who were very active at the time and with an agenda better connected to the Brazilian reality, under the influence of the aforementioned Programa Cultura Viva (Living Culture Programme).

Together with the Garoa, which became the main reference in the hackerspace movement in the country, it is worth mentioning the Matehackers, in Porto Alegre, Rio Grande do Sul, and the Raul Hacker Club, in Salvador, Bahia, as two important influences of the hacker movement in the Southern and Northeastern regions of Brazil respectively. The idea of creating a hackerspace in Porto Alegre also arose from within the university, among IT students from the Universidade Federal do Rio Grande do Sul (Federal University of Rio Grande do Sul), in 2011. In the same year, a room was rented in a collaborative coworking space in the city, the Bunker360, financed by the 


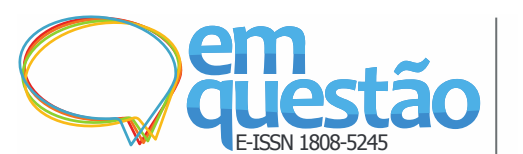

Hackerspace movement: a study of the Brazilian experience

Beatriz Cintra Martins e Sarita Albagli

participants themselves (BURTET, 2014). In Salvador, the mobilization aimed at creating a hackerspace started in 2012 with itinerant meetings in bars, squares and other public spaces. Two years later, in 2014, promoters of this initiative managed to rent a space financed with their own resources as well as by donations, where they started developing projects aimed at the production of some social benefit or criticism (MENEZES; PRETTO, 2015).

\section{Spaces and Strategies}

We present, under this topic, a summarized version of data collected through the questionnaire that aimed at characterizing the motivation for the creation of Brazilian hackerspaces, their infrastructure, participant profile, types of activities implemented and funding options ${ }^{14}$.

Following the method and criteria described in Section 2, we ended up with a list of 21 active hackerspaces in Brazil ${ }^{15}$ in May 2017 which constituted the universe of our research. They are listed in Table 1, divided by region in the country:

Table 1 - Hackerspaces in Brazil

\begin{tabular}{|c|c|}
\hline $\begin{array}{c}\text { Regions of } \\
\text { Brazil } \\
\end{array}$ & Hackerspaces \\
\hline Centre-West & $\begin{array}{l}\text { Calango Hacker Club - Brasília/DF } \\
\text { Cora Hacker Clube - Goiânia/GO }\end{array}$ \\
\hline Northeast & $\begin{array}{c}\text { 0xe Hacker Club - Maceió/AL } \\
\text { CG Hackspace - Campina Grande/PB } \\
\text { [ForHacker]space - Fortaleza/CE } \\
\text { Mandacaru Hackerspace - Feira de Santana/BA } \\
\text { Raul Hacker Club - Salvador/BA } \\
\text { Teresina Hacker Clube - Teresina/PI }\end{array}$ \\
\hline Southeast & $\begin{array}{c}\text { Área31 - Belo Horizonte/MG } \\
\text { Baia Hacker - Itu and Porto Feliz/SP } \\
\text { Carioca Hackerspace - Rio de Janeiro/RJ } \\
\text { Garoa Hacker Clube - São Paulo/SP } \\
\text { Laboratório Hacker de Campinas - Campinas/SP } \\
\text { Maria Lab - São Paulo/SP } \\
\text { Oeste Hacker Clube - Bauru/SP } \\
\text { Rio Hacker Space - Rio de Janeiro/RJ }\end{array}$ \\
\hline South & $\begin{array}{c}\text { Hackerspace Maringá - Maringá/PR } \\
\text { Laboratório Hacker - Santiago/RS } \\
\text { Londrina Hacker Club - Londrina/PR } \\
\text { MateHackers - Porto Alegre/RS } \\
\text { Tarrafa Hackerspace - Florianópolis/SC }\end{array}$ \\
\hline
\end{tabular}


Sent to those 21 initiatives, the questionnaire obtained 16 full answers ${ }^{16}$, representing a return index of around $75 \%$. Among the respondents, $3 / 4$ are founders of the hackerspace or have been part of it from the start of its activities. In order to offer a more representative view of results we highlighted the main options selected by respondents for each question.

The first question sought to identify the motivation underlying the creation of the space (Table 2). The emphasis on the interest in socialization and collaborative production stands out. A degree of social concern and an entrepreneurial slant can also be observed in some of the cases. It is important to bear in mind that respondents could select as many options as they considered relevant.

Table 2 - What motivated the creation of the hackerspace? (choose all the relevant options)

\begin{tabular}{c|c}
\hline Answers & Respondents \\
\hline To produce things in collaboration with others & All (16) \\
\hline To exchange ideas about technology & Almost all (15) \\
\hline $\begin{array}{c}\text { To create things for fun } \\
\text { Leisure and/or entertainment }\end{array}$ & Almost all (14) \\
\hline To invent useful things & Around $2 / 3(11)$ \\
\hline $\begin{array}{c}\text { To look for solution for social and political } \\
\text { problems }\end{array}$ & A little more than half (9) \\
\hline To develop innovation prototypes & Half (8) \\
\hline
\end{tabular}

Source: Devised by the authors.

With regard to the associates' profile (Table 3), the answers show a significant presence of the university and school community in these spaces, both of teachers and of students. As could be expected, the participation of IT professionals is also large. It is worth mentioning that, besides the options offered, in several cases respondents added other profiles not directly related to technology, such as artist, anthropologist, musician, business administrator or simply people with no specific educational background, giving evidence of a certain diversity in the participating audience.

Table 3 - Associates' profile (choose all applicable options)

\begin{tabular}{c|c}
\hline Answers & Respondents \\
\hline Undergraduate students & All have (16) \\
\hline Post graduate students & Almost all have (15) \\
\hline IT professionals & Around $4 / 5$ have (13) \\
\hline University teachers & Around $2 / 3$ have (11) \\
\hline
\end{tabular}




\begin{tabular}{c|c}
\hline & $\begin{array}{l}\text { Hackerspace movement: a study of the Brazilian } \\
\text { experience } \\
\text { Beatriz Cintra Martins e Sarita Albagli }\end{array}$ \\
\hline Engineers & Half have (8) \\
\hline Designers & $\begin{array}{c}\text { A little less then half } \\
\text { have (7) }\end{array}$ \\
\hline $\begin{array}{c}\text { High School students } \\
\text { High School teachers } \\
\text { Media professionals }\end{array}$ & Around $1 / 3$ have (6) \\
\hline Architects
\end{tabular}

Answers concerning sources of funding (Table 4) confirmed the quest for independence and autonomy as a hackerspace differential. In this respect, we observed two exceptions. One of them is the Laboratório Hacker (LabHacker), created and maintained by the Universidade Regional Integrada do Alto Uruguai e das Missões - URI (Regional Integrated University of Alto Uruguai and Missões), in the town of Santiago in the state of Rio Grande do Sul. This initiative, which operates in connection with the course in Computer Science, also confirms the close relationship between hackerspaces and universities. The second exception is the Baia Hacker, which receives funds from the NonGovernmental Organization (NGO) Caminho das Águas. There, we could observe, while visiting the place, that the same people who lead the NGO are also those most active in the hackerspace. We also observed that, besides regular contributions from associates and sporadic ones from collaborators, several hackerspaces have other sources of income such as the sale of T-shirts and stickers, lunches, parties, raffles, etc.

Table 4 - Sources of funding

\begin{tabular}{c|c}
\hline Answers & Respondents \\
\hline Regular contributions from associates & Around $2 / 3(11)$ \\
\hline Sporadic contributions from collaborators & A little below $2 / 3(10)$ \\
\hline Crowdfunding campaigns & A quarter $(1 / 4)(4)$ \\
\hline Financial support from NGO & One (1) \\
\hline Financial support from University & One (1) \\
\hline Source: Devised by the authors.
\end{tabular}

Concerning partnerships with other institutions (Table 5), one can observe that hackerspaces are alternative spaces to formal teaching and research institutions, while at the same time frequently articulating with these and other actors and institutions. Universities are the most frequent partner in projects and activities mainly because, as we have stated previously, students and university teachers are regularly present in these spaces. Besides the case of LabHacker, 


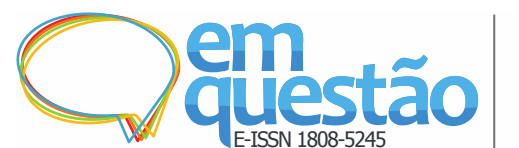

Hackerspace movement: a study of the Brazilian experience

Beatriz Cintra Martins e Sarita Albagli

which is linked to the University's structure, we can highlight the example of Tarrafa Hackerspace. By the occasion it was being established in the city of Florianópolis, some of its members participated in talks and workshops of the course on Ateliê Livre Tecnologias Interativas e Processos de Criação (Free Workshop of Interactive Technologies and Creative Processes) given by Professor José Ripper Kós, at the Universidade Federal de Santa Catarina UFSC (Federal University of Santa Catarina). In exchange for the support for the course, the Tarrafa started using the space of the university for other activities and ended up by being incorporated into the academic extension project coordinated by Professor Kós, the Laboratório em Tecnologias Emergentes, Inovação e Projeto (Laboratory for Emerging Technologies, Innovation and Projects), in a process of mutual cooperation (MATTOS, 2014).

High schools also turn up in the answers about collaborations, and, in a smaller number, governmental departments. In two instances, there is partnership with technology incubators and, in one, with a business. Regarding other instances, joint activities were mentioned with feminists and free software collectives, among other social groups. Finally, in one example a partnership was reported with a fablab and with the Serviço Social do Comércio - SESC (Trade Social Service).

Table 5 - Do you develop activities and projects in collaboration with other institutions?

\begin{tabular}{c|c}
\hline Answers & Respondents \\
\hline Universities & Three quarters (3/4) (12) \\
\hline High schools & A little less than half (7) \\
\hline Governmental departments & A little less than $1 / 3(5)$ \\
\hline Technological incubators & Two (2) \\
\hline A business & One (1) \\
\hline \multicolumn{2}{c}{ Source: Devised by the authors. }
\end{tabular}

Questionnaire responses on the topic of infrastructure (Table 6) showed a somewhat disparate picture. Around 2/3 of respondents believe that the available infrastructure meets all or part of their needs. Two respondents still do not have their own headquarters. Among the 14 responding hackerspaces with headquarters, a little over 1/3 (4) would like to have more space to better entertain the audiences interested in the activities. Even though the equipment infrastructure also varies considerably, almost all the spaces have Arduino ${ }^{17}$, 


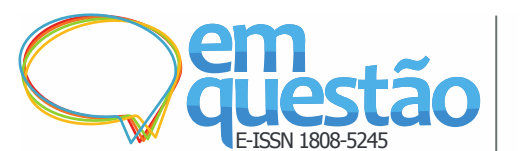

Hackerspace movement: a study of the Brazilian experience

Beatriz Cintra Martins e Sarita Albagli

half have 3D printers and few have a milling machine. In some cases, the following tools were also mentioned: equipment for urban agriculture, sewing machine, kitchen, musical instruments and projectors.

Table 6 - Technical and technological infrastructure (check the available ones)

\begin{tabular}{c|c}
\hline Answers & Respondents \\
\hline Computer & Almost all (14) \\
Arduino & Three quarters 3/4 (12) \\
\hline Developing kits & Around 2/3 (11) \\
\hline Sound equipment & A little below $2 / 3(10)$ \\
\hline Regular printer & Little more than half (9) \\
\hline Videogame & Half (8) \\
Server & \\
3D printer & Around $1 / 5(3)$ \\
\hline Woodwork tools & \\
\hline Milling machine
\end{tabular}

Source: Devised by the authors.

Activities carried out by hackerspaces reveal another difference in relation to fablabs and makerspaces. Together with workshops and activities with greater connection with digital technology and meetings with a focus on project development, diverse social meetings and discussion sessions on varied topics are frequently organized. All respondents (Table 7) claimed that the hackerspace in which they participate is open to the public (depending, most of the time, only on the availability of an associate member to open the space) and that most of the activities are free ${ }^{18}$. However, among the hackerspaces identified during the early stages of the research, one (Area 31 Hackerspace, in Belo Horizonte, Minas Gerais), which did not answer the questionnaire, explicitly states on its web site that it is not open to the general public (ÁREA31, 2019).

Arduino open-sourced platform, the Internet of Things (IoT), cryptography, robotics, programming languages, woodwork, and beer production were among the examples of workshop topics carried out in these spaces. The list of projects being developed was quite varied: Internet of Things (IoT), games, mesh network, transparency in public expenditure, 3D printers, open/ closed sensor of space, recycling of electronic garbage, urban vegetable garden, etc. Games, automation, energy generating bicycles, infinity mirrors, and low cost protheses were mentioned as prototypes, among others. Social 


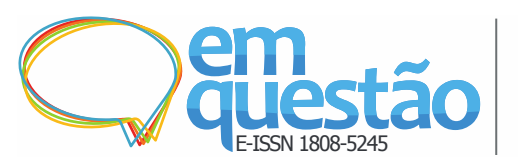

\section{Hackerspace movement: a study of the Brazilian experience \\ Beatriz Cintra Martins e Sarita Albagli}

meetings varied from pizza workshops, barbecues, cultural parties, festivals, film debates, other types of parties and even camping. Discussion meetings touch on themes that vary from digital culture to gender issues. On this last topic, it is worth noticing that, even though gender was not an aspect initially investigated by the research, gender-related issues came up spontaneously in the answers of six hackerspaces when reporting on the type of activity developed and on partnerships established with other collectives. Besides these examples, there is the MariaLab which presents itself as a feminist hacker collective.

Table 7 - Types of activities (check all applicable options)

\begin{tabular}{c|c}
\hline Answers & Respondents \\
\hline Workshops & Almost all (14) \\
\hline Projects & Around 4/5 (13) \\
\hline Social meetings & Three quarters $3 / 4(12)$ \\
\hline Discussion sessions & A little below $2 / 3(10)$ \\
\hline Courses & Little more than half (9) \\
\hline Prototypes & Around $1 / 3(6)$ \\
\hline Hackatons & A quarter $1 / 4(4)$
\end{tabular}

Source: Devised by the authors.

Concerning the recording and documentation of activities and projects (Table 8), it can be noticed that the preference is for doing this on sites, blogs or wikis. Half of them also record on video and a little more than half posts on social networks, particularly on Facebook. In some cases, reports and spreadsheets are elaborated. Even though we verified the interest of the great majority of spaces in recording their activities, we did not check each one in order to check the quality of records or to what extent, in the case of projects and prototypes, these records offer the possibility of reproducing or replicating experiments.

Table 8 - Are your activities and projects recorded in any manner?

\begin{tabular}{c|c}
\hline Answers & Respondents \\
\hline Wikis & Around $2 / 3(11)$ \\
\hline Sites and blogs & A little below $2 / 3 \quad(10)$ \\
\hline Videos & A little more than half (9) \\
\hline Social networks & A little less than $1 / 3 \quad(5)$ \\
\hline Reports & A quarter $1 / 4(4)$ \\
\hline Spreadsheets & Around $1 / 5(3)$ \\
\hline
\end{tabular}

Source: Devised by the authors. 


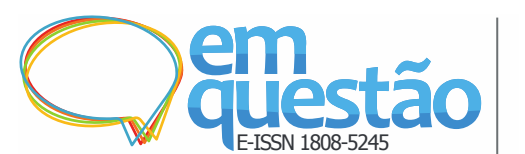

Through responses to the questionnaire, we sought to draw a general characterization of the hackerspace movement in Brazil. We observed that what most motivated participants is the production of things in collaboration with others, together with the creation of things for fun as well as the sharing of ideas about technology and socializing. The importance of sharing knowledge is corroborated by Burtet (2014) who highlights the words of participants of several hackerspaces in the country (MateHackers, Raul Hacker Club, MariaLab, etc.) that emphasize being together, exchanging and collaborating as guiding principles of their actions.

The close ties of these spaces with academia are evident both in the profile of participants who, in their majority, also belong to the academic community, as in the answers about collaboration with other institutions, in which universities appear prominently.

As for the hackerspace's infrastructure, it was noticed that they vary a lot throughout the country. There are better structured hackerspaces, particularly in large capitals, as well as more modest ones in smaller cities; and two of hackerspaces answering the questionnaire do not have their own space. Some of the older ones are well equipped, whereas others are just starting to get organized. Concerning financing, it was observed that regular contribution of associates and sporadic contributions of collaborators are prevalent.

Finally, answers show that the activities carried out go beyond the making together of maker culture to being together, to coexistence, as evidenced by the variety of social meetings and discussion sessions regularly promoted. In some cases, it can be noticed that the space brings together a diversity of participants and of interests that go beyond technological experimentation. This point will be further developed hereafter.

\section{Pathways: Hackerspaces and local agendas}

Using the Garoa as a reference marked by an emphasis on the creative exploration of technology, a variety of experiences have materialized in the hackerspace movement in Brazil. Within this topic, we present some examples identified on the basis of answers to the questionnaire. By considering them, we approach the question raised by Smith et al. (2017) concerning the capacity of 


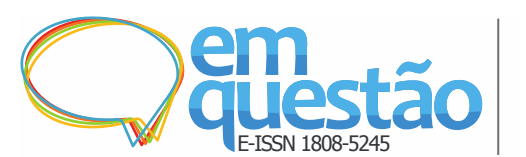

Hackerspace movement: a study of the Brazilian experience

Beatriz Cintra Martins e Sarita Albagli

these spaces to go beyond prototyping, in order to become integrated into a broader social perspective in articulation with other movements and actors, so that the tools developed may contribute to building alternatives of deeper transformations. We do not intend here to defend that only actions focused on local agendas are capable of contributing to more significant social change as, in agreement with Söderberg (2008), we understand that hacking itself has a disruptive effect in relation to the hegemonic perspective in the production of knowledge. However, we were interested in exploring the initiatives in which there is a combination between experimentation in these spaces and engagement in social causes.

One example is the LabHacker, in Rio Grande do Sul state, already mentioned in section 6 for its link with the University. Roger Godoy (GODOY, 2017), one of the participants in this hackerspace, reports that an annual campaign is organized, in partnership with the town council, to collect electronic garbage in the town and surrounding areas. As a result of these campaigns, they receive up to two trucks full of useless or damaged equipment. Part of this material is recycled by the project Lixo é Luxo (Garbage is Luxury), in partnership with the Architecture course of the same university, and made into furniture or decorative objects. Another part is restored and donated to the community as re-shaped equipment and/or components that can be used independently, such as mouse or key-board. Parts that cannot be re-used or recycled are returned to the town council which has a programme for electronic disposal.

On the one hand, this project caters to a need to manage the electronic garbage in the region, identified as a serious contemporary issue as inadequate disposal has considerable effects on the environment without an adequate national response to the issue. On the other, it concretely allows IT students, who are often more focused on topics concerning software and programming, to broaden their learning by having the opportunity of handling equipment and better understanding the way they work.

Another hackerspace with a project related to local environmental issues is the Calango Hacker Clube, in Brasília. The need to obtain reliable data on humidity indexes in the federal capital - a critical problem in the region with an 


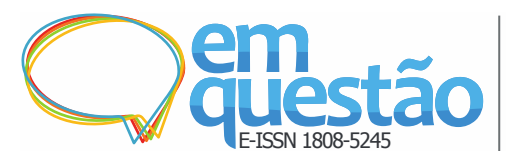

important impact on public health, motivated the creation of the project Monitora Cerrado (Cerrado Monitoring) - Sistema de Monitoramento Climático Distribuído - SMCD (Distributed - System for Climate Monitoring) ${ }^{19}$. The proposal to develop equipment to independently carry out these measurements started being discussed in 2011 as part of the Semana Nacional de Ciência e Tecnologia (National Week for Science and Technology) ${ }^{20}$ of that year, which had climatic changes, natural disasters and risk prevention as its main theme. However, this proposal only took shape in 2017 , with new technology that made possible its implantation.

According to Otávio Carneiro (CARNEIRO, 2017) one of the members of the hackerspace, this is novel technology developed by Calango members. If, at the start of the project, the main motivation was the concern with the likely manipulation of official indexes, the resuming of the project took place as a result of the interest in experimenting with the development of new technology. Anyway, even though it is still being adjusted, the project offers an alternative to the local population. In December 2017 there were 11 stations for monitoring humidity and temperature in different places of the region ${ }^{21}$, such as Vila Planalto, Altiplano, Águas Claras and Sobradinho, among others. Data is available online and can be conferred in real time by the inhabitants of Brasília (MONITORA CERRADO, [2019]) ${ }^{22}$. The recording, however, is still only partial as not all stations operate in a stable and continuous manner.

Another example of diversity in these spaces comes from the Northeast of the country. The Teresina Hacker Clube, in the capital of the state of Piauí, aims to use knowledge to overcome problems of a social, political or economic nature, preferably regional problems (COSTA, 2017). Among the projects developed there are: the Salve o Angico (Save the Angico), a hot site to collect signatures against the indiscriminate felling of the Angico Branco, a tree native to the region; and the Mão Amiga (Friendly Hand), concerned with the development of low cost prosthesis for disabled people with the help of 3D printers, bearing in mind the shortage of such devices at the Centro Integrado de Reabilitação do Estado do Piauí - CEIR (Integrated Center for Rehabilitation of the state of Piauí). 


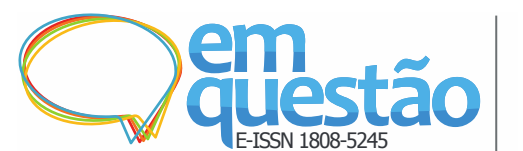

Hackerspace movement: a study of the Brazilian experience

Beatriz Cintra Martins e Sarita Albagli

The outstanding example, both in reach and scope, is the Indexador de Dados Públicos Peba (Peba Index of Public Data). Launched in 2014 during the event Open Data Day ${ }^{23}$ in the city. The programme carries out searches of data related to the expenditure of elected representatives all over the country, using as source sites of the House of Representatives. Despite the fact that Brazil already has legislation compelling the Federal Government, states and municipalities to disclose their expenditure on the internet in real time, systems are still opaque and make it difficult to people to have access to information of public relevance. Lucas Costa (COSTA, 2017), one of the programme developers, explains that one of the objectives of Peba is to make this access easier and simpler to common citizens and, with time, he intends to expand the search to other types of public information ${ }^{24}$. Still in beta version in 2017 , the programme allows for searches by name, party, state, supplier, Internal Revenue number for individuals and businesses (CPF and CNPJ) as well as giving access to invoices concerning expenditure by elected representatives.

The final instance we would like to report is unquestionably the most diverse. At the Baia Hacker Space with headquarters both in Itu and in Porto Feliz, in the interior of the state of São Paulo, technology is not the center of attention but an auxiliary tool to develop different projects. One of the clues to this difference in relation to other hackerspaces is the profile of participants. Side by side with a few people with IT education are predominantly people with a humanistic background such as social scientists, administrators, artists, photographers, musicians, designers, theater people, etc. Besides, because it is located in small towns, without formal institutions for displaying local creative production, the hackerspace has become a center for bringing together people in the area who were searching for an alternative space for implementing their projects. Defining itself as a temporary lab for sensitive experiences, the Baia is also articulated to small business in the area with which it develops projects such as pallets workshops, composting workshops, developing filters for water, etc.

At their urban center in Itu, which takes up two rooms in a business incubator at the local city council, the emphasis is on cultural production. Three editions of the Sarau Hacker, which has gathered together artists, artisans, 


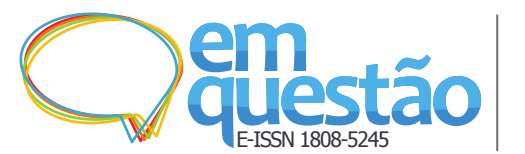

Hackerspace movement: a study of the Brazilian experience

Beatriz Cintra Martins e Sarita Albagli

photographers, musicians, poets, chefs, among others, pushed forward the creation of a network of creative economy. The space also hosted the production of the Festival Lado B (B Side Festival), which took place in July 2017, and occupied eight different spaces in the town for 20 days to introduce new artists, usually ignored by the local council's Cultural Department. For artists taking part in the Baia, the idea of hacking goes beyond codes and technologies: the point is to hacker the town's official culture.

At the rural headquarters, in Colônia Capoava (Capoava Community) in the town of Porto Feliz, the focus is on research on sustainability. In an area of around 54 hectares where about 400 people live, the project named Porto Rural (Rural Port) $^{25}$ has as its goal to research protocols and prototypes for technological services and products within the concept of permaculture, which relies on the planning of environmentally sustainable, socially fair and financially viable systems. Carlos Diego Rodrigues, one of the members of the hackerspace, reports that the project still is at its initial phase and has a timeline of 15 years, up to 2032, for its full implantation. At present, the area is undergoing a process of donation to Caminho das Águas, the financier and partner of Baia Hacker, which will be then responsible for managing the community.

It is worth pointing out, however, that an important differential in these four reported cases regards the effective capacity of carrying out each project. The initiative of recycling electronic garbage of the LabHacker is completed each year, constituting in fact in a drainage channel for these materials in the region. Likewise, cultural productions of the Baia Hacker create concrete spaces for the presentation and exhibition of town artists as well as for the promotion of part of the local creative economy. On the other hand, the Peba project, developed by the Teresina HC, as well as by the Monitora Cerrado (Cerrado Monitoring), of the Calango HC, are limited by the shortage of both financial and human resources, preventing them to achieve their intended goals. They are valuable proposals for the local population, but with still limited achievements.

As previously highlighted, a point in common between the LabHacker and the Baia Hacker is that both articulate with other actors and/or institutions in the completion of their projects. The first one is connected to a federal 


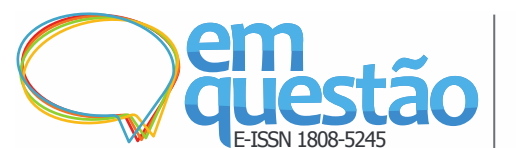

Hackerspace movement: a study of the Brazilian experience

Beatriz Cintra Martins e Sarita Albagli

university and the activity is carried out in conjunction with the local town hall. The second one is articulated with several actors in the region, with the town hall and small businesses, besides relying on a partnership with an NGO. This could be an important indicator of the reason why its initiatives have had better and more comprehensive final results. It is worth remembering that one of the questions raised by Smith et al. (2017) in connection with hackerspaces refers exactly to the need to articulate with other movements and actors to achieve a more encompassing social perspective. We could add that not only the perspective, but the very concretization of their actions depends on these partnerships.

\section{Final Considerations}

The panorama of initiatives hereby presented, in different regions of Brazil, displays the variety of the hackerspace movement in Brazil. With different configurations, infrastructure, financing models and types of activities, Brazilian hackerspaces have in common the emphasis on face-to-face conviviality, on producing things and creatively exploring technology together, always motivated by experimentation and the sharing of information and knowledge.

Furthermore, it shows that some of them are also connected to the search for solutions to social problems and contemporary challenges. Their activities and production are the result of the interaction between people with different profiles, with complementary abilities and competences. As centers for articulating different actors and diverse areas of knowledge, they constitute privileged spaces for the creation of varied prototypes of citizen innovation, such as low-cost prosthesis and energy-generating bicycles, sustainability in disposing of electronic garbage, citizen monitoring of the environment, transparency in public data, and even the creation of alternative networks of cultural production. These are not final answers with finished products, but open and continuous processes of experimentation that deserve to be more closely monitored as instances of bottom-up innovation.

As pointed out by Smith and Light (2017), hackerspaces contribute in a concrete manner to the circulation of technical and technological knowledge throughout different spaces and sectors of society. They must be seen as 


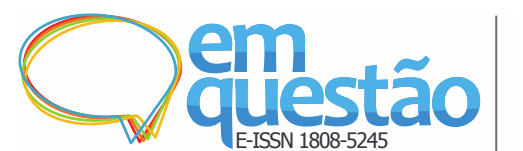

Hackerspace movement: a study of the Brazilian experience

Beatriz Cintra Martins e Sarita Albagli

innovative spaces and forms of social appropriation of technology and knowledge, as key factors of social appropriation of cities and of social change.

\section{References}

ALBAGLI, Sarita. Open science in question. In: ALBAGLI, Sarita; MACIEL, Maria Lucia; ABDO, Alexandre Hannud (Ed.). Open science, open issues. Brasília: IBICT; Rio de Janeiro:Unirio, 2015. p. 9-25. Available at: http://livroaberto.ibict.br/handle/1/1061. Accessed on 3 Nov. 2019.

ÁREA31. Hackerspace. Belo Horizonte, 2019. Available at: https://area31.net.br/wiki/P\%C3\%A1gina_principal. Accessed on: 25 Jan. 2019.

BARCO HACKER. Belém: 2013. Facebook: barcohacker.br. Available at: https://www.facebook.com/pg/barcohacker/about/?ref=page_internal. Accessed on: 3 Nov 2019.

BURTET, Cecilia Gerhardt. Os saberes desenvolvidos nas práticas de um hackerspace de Porto Alegre. 2014. Dissertação (Mestrado em Administração) - Programa de Pós-Graduação em Administração, Universidade Federal do Rio Grande do Sul, Porto Alegre, 2014.

CÂMARA DOS DEPUTADOS. LABHacker. Brasil, [2018]. Available at: http://labhackercd.leg.br/. Accessed on: 3 Nov. 2019.

CARNEIRO, Otávio. Otavio Carneiro: interview [Oct.2017]. Interviewer: Beatriz Cintra Martins. Rio de Janeiro, 2017. $1 \mathrm{mp} 4$ file (48 min).

COLEMAN, Enid Gabriella. Coding Freedom: the ethics and aesthetics of hacking. New Jersey: Princeton, 2013.

COSTA, Lucas. Lucas Costa: interview [Oct.2017]. Interviewer: Beatriz Cintra Martins. Rio de Janeiro, 2017. $1 \mathrm{mp} 4$ file (30 min).

FONSECA, Felipe. Redelabs: laboratórios experimentais em rede. 2014. Dissertação (Mestrado em Divulgação Ciêntífica e Cultural) - Instituto de Estudos da Linguagem, Universidade Estadual de Campinas, Campinas, 2014.

GAROA HACKER CLUBE. Hackerspaces Brasileiros. [S. l.], 2019. Available at: https://garoa.net.br/wiki/Hackerspaces_Brasileiros. Accessed on: 25 Jan. 2019. GAROA HACKER CLUBE. Sede. [S. l.], 2018. Available at: https://garoa.net.br/wiki/Sede. Accessed on 3 Nov. 2019.

GAROA HACKER CLUBE. História. [S. l.], 2015. Available at: https://garoa.net.br/wiki/Hist\%C3\%B3ria. Accessed on: 3 Nov. 2019. 


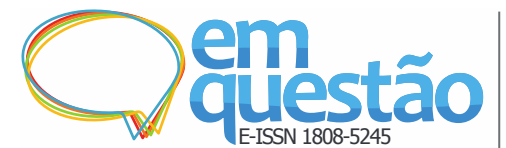

Hackerspace movement: a study of the Brazilian experience

Beatriz Cintra Martins e Sarita Albagli

GAROA HACKER CLUBE. Estatuto. [S. l.], 2013. Available at: https://garoa.net.br/wiki/Estatuto. Accessed on: 3 Nov. 2019.

GODOY, Roger. Roger Godoy: interview [Oct.2017]. Interviewer: Beatriz Cintra Martins. Rio de Janeiro, 2017. $1 \mathrm{mp} 4$ file (25 min).

GRENZFURTHNER, Johannes; SCHNEIDER, Frank Apunkt. Hacking the spaces. [S. l.: s. n.], 2009.HACKERSPACE.ORG. Hackerspaces. [S. l.], 2018. Available at: http://hackerspaces.org. Accessed on: 25 Jan. 2019.

LEVY, Steven. Hackers: heroes of the computer revolution. New York: Penguin Books, 2001.

MARTINS, Beatriz Cintra; ALBAGLI, Sarita. Hackerspace movement: a study of the Brazilian experience. Zenodo [Repository]. 5 May 2019. DOI: 10.5281/zenodo.2667643. Available at: https://zenodo.org/record/2667643. Acessed on: 5 Nov. 2019.

MATTOS, Erica Azevedo da Costa. Ethos Hacker e Hackerspaces: práticas e processos de aprendizagem, criação e intervenção. 2014. Dissertação (Mestrado em Urbanismo, Histório e Arquitetura da Cidade) - Programa de PósGraduação em Urbanismo, História e Arquitetura da Cidade, Universidade Federal de Santa Catarina, Florianópolis, 2014.

MAXIGAS, Peter. Hacklabs and Hackerspaces: Tracing Two Genealogies. Journal of Peer Production, [S. l.], n. 2, 2012. Available at: http://peerproduction.net/editsuite/issues/issue-2/peer-reviewedpapers/hacklabs-and-hackerspaces/. Accessed on: 2 Nov. 2019.

MENEZES, Karina Moreira; PRETTO, Nelson de Luca. Hackerspaces à brasileira: sociabilidade, diversidade e tecnologias. In: SEMINÁRIO INTERNACIONAL AS REDES EDUCATIVAS E AS TECNOLOGIAS: MOVIMENTOS SOCIAIS E EDUCAÇÃO, 8., 2015, Rio de Janeiro. Anais [...]. Rio de Janeiro: Universidade do Estado do Rio de Janeiro, 2015. Available at: http://www.seminarioredes.com.br/viiiredes/adm/diagramados/TR341.pdf. Acessed on: 2 Nov. 2019.

MINISTÉRIO DA CIDADANIA. Cultura viva. [S. l.]: Secretaria Especial da Cultura, [2018]. Available at: http://www.cultura.gov.br/cultura-viva. Access on: 3 Nov. 2019.

MOILANEN, Jarkko. Emerging Hackerspaces: peer-production generation. In: Hammouda, I. et al. (ed.). Open Source Systems: long-term sustainability. Berlin: Springer, 2012. p. 94-111.

MONITORA CERRADO. [S. l.], [ 2019]. Available at: http://monitoracerrado.org/. Accessed on: 3 Nov. 2019. 


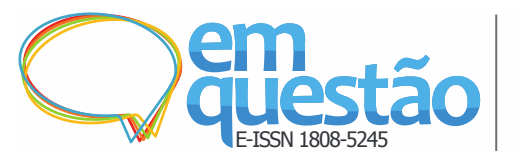

Hackerspace movement: a study of the Brazilian experience

Beatriz Cintra Martins e Sarita Albagli

NING. California, [2018]. Available at: https://www.ning.com/. Access on: 3 Nov. 2019.

ÔNIBUS Hacker. São Paulo, 2011. Facebook: onibushacker.br. Available at: https://www.facebook.com/pg/onibushacker/about/?ref=page_internal. Accessed on: 3 Nov. 2019.

PETTIS, Bre; SCHNEEWEISZ, Astera; OHLIG, Jens (ed.). Hackerspaces: the_beginning[S. l.: s. n. $],$ 2011. Available at:

https://archive.org/details/hackerspaces-the-beginning. Access on: 25 Jan. 2019.

PORTO RURAL. 2019. Available at: https://portorural.com.br/. Accessed on: 3 Nov, 2019.

RAMALHO, Luciano. Luciano Ramalho: interview [nov. 2013]. Interviewer: Sarita Albagli. São Paulo: Garoa Hacker Clube, 2013. 1 mp4 file (53 min).

SMITH, Adrian; LIGHT, Ann. Cultivating sustainable developments with makerspaces. Liinc em Revista, Rio de Janeiro, v. 13, n. 1, p. 162-174, 2017. DOI: https://doi.org/10.18617/liinc.v13i1.3900

SMITH, Adrian; FRESSOLI, Mariano; ABROL, Dinesh; AROND, Elisa; ELY, Adrian. Grassroots innovation movements: pathways to sustainability.

London: Routledge, 2017.

SÖDERBERG, Johan. Hacking Capitalism: The Free and Open Source Software Movement. New York: Routledge, 2008.

\title{
Movimento hackerspace: um estudo sobre a experiência brasileira
}

\begin{abstract}
Resumo: Os hackerspaces fazem parte de fenômeno emergente em todo o mundo de construção de espaços e infraestruturas alternativos de pesquisa, experimentação e aprendizado. Diferenciam-se de outros espaços institucionalmente estabelecidos por seus princípios de autonomia: são financiados e geridos por seus próprios membros e, logo, têm maior liberdade para definirem seus temas e questões. Neste artigo, apresentamos os resultados de pesquisa realizada, em 2017, sobre os hackerspaces brasileiros. Na análise, recorremos à estrutura proposta por Smith et al. (2017) em seu estudo sobre movimentos de inovação de base, organizada em quatro aspectos que se complementam, quais sejam: contexto, enquadramento, espaços e estratégias, e caminhos. Assim, abordamos a história do movimento no Brasil; sentidos e narrativas compartilhados pelos participantes; espaços e estratégias utilizados em sua estrutura e organização; e, finalmente, os estudos de casos selecionados por se articularem com questões da comunidade local. A pesquisa identificou 21 hackerspaces ativos no país em 2017, distribuídos pelas regiões Centro-Oeste, Nordeste, Sudeste e Sul. Destes, 16 responderam a um questionário que revelou
\end{abstract}




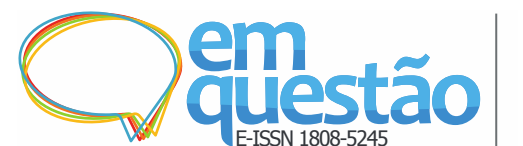

a diversidade das atividades desenvolvidas e a proximidade dessas iniciativas com a comunidade universitária, dentre outras características. Já os estudos de caso evidenciaram que, além de contribuírem para a mais ampla circulação do conhecimento tecnológico, os hackerspaces também são espaços para o desenvolvimento de práticas e tecnologias que buscam responder a questões sociais e ambientais, como a sustentabilidade no descarte do lixo eletrônico e o monitoramento cidadão do meio ambiente.

Palavras-chave: Hackerspace. Inovação de base. Ciência cidadã.

Recebido: 28/01/2019

Aceito: 02/06/2019

${ }^{1}$ We can include among these initiatives, inspired by hacker culture without self-denomination as such: the LabHacker da Câmara dos Deputados ([2018]), the Barco Hacker (2013), from Belém, Pará, and the Ônibus Hacker (2011), from São Paulo.

${ }^{2}$ Despite the fact that there is great diversity among hackers and one cannot claim that they all share the same values, as indicated by Coleman (2013), hacker ethics described by Levy (2001) established certain imperatives that served as a basis for hackers to think about themselves and about their activity, shaping it into a set of standards for this community.

${ }^{3}$ Those aspects were pointed out by Luciano Ramalho, of the Garoa Hacker Club (RAMALHO, 2013).

${ }^{4}$ We will limit ourselves to the history of hackerspaces in Brazil. On the history of hackerspaces in the world, refer to Maxigas (2012), Grenzfurthner and Schneider (2009) and Pettis, Schneeweisz and Ohlig (2011).

${ }^{5}$ It is a self-organized network that proposes the de-construction of technology aiming at social transformation.

${ }^{6}$ Further information at Ministério da Cidadania ([2018]).

${ }^{7}$ Pontos de Cultura (Culture Points) are groups, collectives and entities that develop and articulate cultural activities in their communities and in network that were recognized and supported by the Living Culture Programme of the Ministry of Culture.

${ }^{8}$ Mutirão is collective action aimed at coping with specific problems such as a group of inhabitants of a community getting together to build an ordinary house. Gambiarra is the invention of useful artefacts using precarious or improvized resources.

${ }^{9}$ Ning ([2018]) is an online platform that allows for the creation of customized virtual communities.

${ }^{10}$ Data obtained in an interview with Alexandre Hannud Abdo, researcher and titular associate of the Garoa, complemented by information available at the hackerspace wiki Garoa Hacker Clube (2015). We would like to take the opportunity to thank the researcher for the information and recommendations that facilitated our contact with these spaces.

${ }^{11}$ Inspired by the São Paulo CCD, there are Casas de Cultura Digital (Homes for Digital Culture) in different cities such Porto Alegre, Belém, Campinas and Vitória.

${ }^{12}$ Further information at Garoa Hacker Clube (2013).

${ }^{13}$ Further information at Garoa Hacker Clube (2018).

14 Research data (questionnaire, answers, interview script, list of hackerspaces active in December 2017 and their websites) are deposited into Zenodo Platform (MARTINS; ALBAGLI, 2019).

${ }^{15}$ It is worth stressing that the hackerspace movement scene is dynamic. In July 2018, we came across the information that another two hackerspaces had been created: the Jerimum 
Hackerspace, at the Federal University of Rio Grande do Norte (Universidade Federal do Rio Grande do Norte), and the Hackerspace IFUSP, at the Physics Institute of the University of São Paulo (Instituto de Física da Universidade de São Paulo).

${ }^{16}$ We had a 17 th incomplete answer that covered only a few of the items of the questionnaire and that was discarded as a result.

${ }^{17}$ Arduino is a platform for electronic prototyping in open hardware and software.

${ }^{18}$ In one of the cases, it was said that there is a small charge for courses or workshops only to cover space maintenance.

19 Within the topic of sustainability, it is worth mentioning the prototype of a bicycle for generating electricity developed by the Calango HC.

20 The National Week of Science and Technology, coordinated by the Ministry for Science, Technology, Innovation and Communication, that has the purpose of bringing Science and Technology closer to people through events that congregate institutions from all over the country around activities of science communication.

${ }^{21}$ Data from December 2017, available at Monitora Cerrado (Monitora Cerrado, 2019).

${ }^{22}$ Further information on the project at Monitora Cerrado (2019).

${ }^{23}$ Open Data Day is a worldwide annual event with the goal of promoting the use of open data.

${ }^{24}$ We registered the existence of another public data scraping project, but we could not obtain more information until the final phase of the research: it is the Laboratorio de Dados para a Cidadania Hacker (Data Laboratory for Hacker Citizenship) that began to be developed in 2017 by Raul Hacker Club, from Salvador / BA)..

${ }^{25}$ Further information about Porto Rural at Porto Rural (2019). 